\title{
Jabatan Notaris Dalam Era Perkembangan Teknologi Informasi Dan Komunikasi
}

\section{Genesia Hardina Memah}

E-mail: genesiahardinamemah@gmail.com

\begin{tabular}{l}
\hline Info Artikel \\
\hline Masuk :31 Januari 2020 \\
Diterima : 2 Februari 2020 \\
Terbit : 30 April 2020 \\
Keywords : \\
Notary,e-government, \\
teleconference \\
\\
\\
DOI : \\
10.24843/AC.2020.v05.i01.p16 \\
Genesia Hardina Memah, \\
E-mail: \\
genesiahardinamemah@gma \\
il.com \\
Kata kunci: \\
Notaris,e-government, \\
\end{tabular}

\section{Info Artike}

Diterima : 2 Februari 2020

Keywords :

Notary,e-government, teleconference

Kata kunci:

\begin{abstract}
The purpose of this research is to find the influences of the development on technology information and communication on the administrative and the material (substantive) aspect to a notary, wherein this research normative legal methodology is conducted with the results as follow there is a positive administrative influence of technology information and communication such as the use of e-government in the communication of notary or candidate of a notary with government and the increased office effectiveness. However, there is also a negative influence such as the ease of publication and self-promotion; thus, the Indonesia Notary Association need to always give direction through a regular meeting. The impact of technology information and communication on the administrative aspect is that it could result on clash between the Law of Notary with other law that already regulate the utilization of technology information and communication where from the theory point of view, the concept of lex specialis derogat legi generali can be used while from the practical perspective, it is preferable to have memorandum of understanding between the Indonesian Notary Association with the Indonesian Nasional Police (Polri).
\end{abstract}

\section{Abstrak}

Tujuan penelitian untuk dapat mengetahui dampak perkembangan teknologi informasi dan komunikasi terhadap aspek administratif dan aspek materi (substansi) terhadap Notaris, penelitian hukum normatif digunakan sebagai metode. Hasil studi penelitian menunjukkan bahwa pengaruh perkembangan teknologi informasi dan komunikasi terhadap aspek administratif ada yang positif, seperti pemanfaatan e-government dalam komunikasi Notaris/Calon Notaris dengan Pemerintah dan peningkatan efektivitas perkantoran, tetapi ada juga segi negatif seperti kemudahan publikasi atau promosi diri, sehingga Ikatan Notaris Indonesia perlu selalu memberi arahan dalam pertempuan berkala. Selanjutnya pengaruh 
perkembangan terhadap aspek materi (substansi) yaitu dapat menimbulkan benturan antara Undang-Undang Jabatan Notaris dengan Undang-Undang lain yang telah mengakomodir pemanfaatan TIK, di mana dalam hal ini dari segi ilmiah dapat digunakan konsep lex specialis derogat legi generali, sedangkan dari segi praktis sebaiknya ada Nota Kesepahaman antara Ikatan Notaris Indonesia dengan Polri.

\section{Pendahuluan}

Didalam zaman globalisasi dewasa ini perkembangan teknologi komunikasi dan informasi adalah tahap penting didalam proses perkembangan suatu negara. Kehidupan masyarakat modern saat ini telah menjadikan teknologi informasi menjadi suatu kebutuhan primer yang harus dipenuhi. Globalisasi TIK menjadikan Indonesia memberikan sumbangan besar dalam kehidupan masyarakat TIK didalam bidang hukum, sosial, ekonomi dan budaya.

Dunia tanpa batas atau yang sering disebut "borderless world" menggambarkan betapa cepatnya teknologi berkembang memiliki peranan penting didalam teknologi dan komunikasi menjadi penghubung antara individu dan kelompok maupun komunitas dan korporasi secara cepat tanpa harus menghadirkan secara berhadapan atau face to face. ${ }^{1}$ Perkembangan TIK yang pesat dengan seiring perkembangan zaman memberi dampak dalam kehidupan termasuk kehidupan kenotariatan di Indonesia.

Notaris memiliki peranan penting didalam suatu hubungan hukum antar masyarakat, sebab hubungan hukum didalam masyarakat membutuhkan sebuah bukti tertulis yaitu suatu akta autentik. Peran notaris ialah sebagai seorang pejabat negara yang melakukan layanan pada masyarakat, diberikan kesempatan untuk memajukan daya dan karya dalam dibidang pengunaan dan manfaat teknologi informasi dan komunikasi seefektif mungkin serta bertanggung jawab dalam pemanfaatannya guna memaksimalkan pelayanan kepada masyarakat. ${ }^{2}$ Serta Notaris diharapkan dapat berpartisipasi dalam perkembangan kemajuan TIK tersebut, sebab didalam suatu transaksi

${ }^{1}$ Ni Ketut Supasti Dharmawan, (2015), Keberadaan Pemegang Saham Dalam Rups Dengan Sistem Teleconference Terkait Jaringan Bermasalah Dalam Perspektif Cyber Law, Udayana Master Law Jurnal, Vol. 4, No.1, Hal. 190

${ }^{2}$ Benny, (2015), Penetapan Konsep Cyber Notary di Indonesia ditinjau dari Undang-Undang Nomor 2 Tahun 2014, Premise Law Jurnal, Vol 5, Hal 15 
elektronik nantinya sangat besar kemungkinan keikutsertaan Notaris sebagai pihak ketiga yang perannya sama seperti didalam suatu transaksi konvensional. ${ }^{3}$ Jasa seorang Notaris saat ini merupakan kebutuhan penting dalam masyarakat bukan hanya saja dalam mebuat akta, tetapi juga sebagai seorang yang tidak berpihak atau netral didalam suatu transaksi. ${ }^{4}$

Menurut Pasal 15 ayat (1) UUJNP menyatakan bahwa "Notaris berwenang membuat Akta autentik mengenai semua perbuatan, perjanjian, dan penetapan yang diharuskan oleh peraturan perundang-undangan dan/atau yang dikehendaki oleh yang berkepentingan untuk dinyatakan dalam Akta autentik, menjamin kepastian tanggal pembuatan Akta, menyimpan Akta, memberikan grosse, salinan dan kutipan Akta, semuanya itu sepanjang pembuatan Akta itu tidak juga ditugaskan atau dikecualikan kepada pejabat lain atau orang lain yang ditetapkan oleh undang-undang."5 Ini merupakan wewenang pokok Notaris. Selain itu Notaris berwenang pula melakukan hal-hal yang ada Pasal 15 ayat (2) UUJNP menyatakan memastikan tanggal surat dibawah tangan dan didaftarkan pada suatu buku yang khusus dan mengesahkan tanda tangan; dan juga menurut Pasal 15 ayat (3) mempunyai suatu kewenangan-kewenangan lainnya yang telah ditentukan didalam undang-undang.

Suatu hal yang penting bagi Notaris, masyarakat dan Negara yaitu apa yang dinamakan Protokol Notaris, yang menurut penjelasan Pasal 62 UUJN, "terdiri atas: a. minuta Akta; b. buku daftar akta atau repertorium; c. buku daftar akta di bawah tangan yang penandatanganannya dilakukan di hadapan Notaris atau akta di bawah tangan yang didaftar; d. buku daftar nama penghadap atau klapper; e. buku daftar protes; f. buku daftar wasiat; dan g. buku daftar lain yang harus disimpan oleh Notaris berdasarkan ketentuan peraturan perundang-undangan." 6 Protokol Notaris ini oleh Pasal 1 angka 13 UUJNP didefinisikan sebagai gabungan dokumen-dokumen adalah suatu arsip negara yang harus dijaga dan diatur sebaik mungkin oleh Notaris berdasarkan peraturan perundang-undangan. Di sini dikatakan bahwa Protokol Notaris

\footnotetext{
${ }^{3}$ Dewa Ayu Widya Sai, R.A Retno Murni, I Made Udiana, (2017), Kewenangan Notaris Di Bidang Cyber Notary Berdasarkan Pasal 15 Ayat (3) Undang-Undang Nomor 2 Tahun 2014 Tentang Perubahan Atas Undang-Undang Nomor 30 Tahun 2004 Tentang Jabatan Notaris, Acta Comitas, Vol 2, Hal 219

${ }^{4}$ Edmon Makarim, (2011), Modernisasi Hukum Notaris Masa Depan: Kajian Hukum Terhadap Kemungkinan Cyber Notary Di Indonesia, Jurnal Hukum Dan Pembangunan Tahun 41, No. 3, Hal 467

${ }^{5}$ Undang-Undang Nomor 30 Tahun 2004 tentang Jabatan Notaris (Lembaran Negara Republik Indonesia Tahun 2004 Nomor 117, Tambahan Lembaran Negara Republik Indonesia Nomor 4432). ${ }^{6}$ Ibid.
} 
adalah arsip negara. Kedudukan Protokol Notaris yang adalah arsip negara sudah tentu menghendaki agar Notaris benar-benar saksama dan memperhatikan peraturan-peraturan hukum yang berlaku waktu menangani dokumen-dokumen yang nantinya akan dimasukkan ke dalam Protokol Notaris.

Perihal tata cara menyimpan minuta akta belum ada aturan hukum yang jelas dan tetap mengatur tentang hal tersebut sehingga tidak adanya aturan hukum yang jelas dan tetap yang mengatur tentang menyimpan minuta, menimbulkan akibat untuk para notaris menyimpan minuta akta yang adalah arsip negara tidak memiliki pegangan hukum yang dijadikan landasan pelaksanaan hal tersebut. ${ }^{7}$ Sehingga menyebebabkan protokol notaris rusak, hilang dan musnah.

Kehadiran TIK dalam dunia kenotariatan sangat dimungkinkan dilakukannya mengelola arsip lewat media elektronik. Media elektronik dengan ini sangat diharapkan nantinya dalam mengelola arsip, yaitu didalamnya termasuk menyimpan protokol notaris dilakukan lebih baik lagi. ${ }^{8}$

Sejarah panjang selama ratusan tahun perkembangan lembaga notariat sehingga sampai pada tahap seperti sekarang ini, belakangan ini menghadapi suatu perkembangan lain yang ada kaitannya dengan Jabatan Notaris, yaitu Teknologi Informasi dan Komunikasi (TIK). Pada tahun 2000, dalam suatu buku telah dikemukakan bahwa,

Together with the rise of information and communication technologies (ICT) and the electronic highway, ICT law has also grown. While various areas of the law have tried to keep pace with the developments in ICT since the 1970an, in the 1990an, it was recognised that the rise of ICT and the electronic highway also have a more fundamental influence on the law as a whole. After all, ICT affects all aspects of social life, and thus, ICT cuts right through all the traditional branches of law. As a result, the question arose how the law as a whole should react to these developments. ${ }^{9}$

Menurut tulisan tersebut, dalam waktu singkat, jalur elektronik telah menaklukkan dunia (Barat). Jika diawal 1990an, hanya beberapa orang pernah

\footnotetext{
${ }^{7}$ Cut Era Fitriyeni, (2012), Tanggung Jawab Notaris Terhadap Penyimpanan Minuta Akta Sebagai Bagian Dari Protokol Notaris, Kanun Jurnal Ilmu Hukum, Tahun XIV, No. 58, Hal. 391

${ }^{8}$ I Made Arya Utama, Desak Putu Dewi Kasih, (2017), Penyimpanan Protokol Notaris Secara Elektronik Dalam Kaitan Cyber Notary, Acta Comitas Vol 2, Hal 172

${ }^{9}$ Bert-Jaap Koops, 2000, Corien Prins dan Hielke Hijmans (ed.), ICT Law and Internationalisation. A Survey of Government Views, Kluwer Law International, Netherland, The Hague, Hal. 83.
} 
mendengar dari email atau internet, hampir sepuluh tahun selanjutnya, teknologi ini mulai berkembang dan dikenal masyarakat luas. Masihlah sangat sulit untuk memberikan kata akhir dari pengaruhnya dalam masyarakat, namun dapat dipastikan bahwa dunia saat ini dengan memiliki jalur cepat elektronik, dalam berbagai cara, telah berfungsi berbeda bahkan lebih baik dari dunia sepuluh tahun yang lalu. Hal ini berdampak pada hukum. Bersama-sama dengan munculnya teknologi informasi dan komunikasi (TIK) dan jalur cepat elektronik, hukum TIK juga telah berkembang. Jika di tahun 1970-an berbagai bidang hukum telah mencoba untuk mengikuti perkembangan TIK, di tahun 1990-an, diakui bahwa munculnya TIK dan jalur cepat elektronik juga memiliki pengaruh yang lebih mendasar pada hukum secara keseluruhan. Lagi pula, TIK telah mempengaruhi semua aspek kehidupan sosial, dan dengan demikian, TIK telah melampaui semua bidang hukum tradisional. Akibatnya, muncul pertanyaan bagaimana hukum secara keseluruhan harus bereaksi terhadap perkembangan ini.

Dalam bidang perdagangan pengaruh TIK dan jalur cepat teknologi telah melahirkan e-commerce, di mana UNCITRAL Model Law on Electronic Commerce with Guide to Enactment 1996 dalam memberikan pedoman untuk pembuatan peraturan e-commerce kepada negara-negara yang berkehendak membuatnya, dalam bagian menimbang mengemukakan bahwa, suatu peningkatan jumlah transaksi didalam suatu perdagangan internasional dilakukan dengan menggunakan cara menukarkan sejumlah data elektronik juga dengan cara berkomunikasi lain, yang umumnya merujuk pada "electronic commerce", yang mana mencakup penggunaan alternatif-alternatif terhadap metode berbasis kertas dalam komunikasi dan penyimpanan informasi. ${ }^{10}$ Selanjutnya dalam bagian Pedoman untuk Penetapan (Guide to Enactment) dikatakan bahwa, komunikasi yang paling penting dilihat dari sisi hukum dalam bentuk pesan tanpa kertas nantinya mungkin akan dihambat oleh rintangan hukum untuk menggunakan pesan seperti itu ${ }^{11}$ Dalam pedoman ini dikemukakan bahwa atau oleh ketidak pastian mengenai akibat hukum dan vailidatas. Didalam pedoman ini dikemukakan bahwa TIK telah melahirkan metode tanpa kertas (paperless method) sebagai salah satu alternatif terhadap metode berbasis kertas (paper-based method).

${ }^{10}$ United Nations,"'UNCITRAL Model Law on Electronic Commerce with Guide to Enactment 1996 with additional article 5 bis as adopted in 1998",

http//www.uncitral.org/pdf/english/texts/electcom/05-89450_Ebook.pdf, diakses tanggal 15/03/2019.

11 Ibid. 
Uraian diatas menimbulkan pertanyaan tentang pengaruh dari perkembangan TIK, yang melahirkan metode tanpa kertas sebagai altrnatif terhadap metode berbasis kertas, terhadap Jabatan Notaris, baik dari aspek administratif maupun dari aspek materi (substansi).

\section{Rumusan Masalah}

1. Bagaimanakah pengaruh dari berkembangannya teknologi informasi dan komunikasi pada aspek administratif dari Jabatan Notaris?

2. Bagaimanakah pengaruh dari berkembangannya teknologi informasi dan komunikasi pada aspek materi (substansi) jabatan Notaris?

Tujuan dilakukannya penelitian ini adalah agar dapat memahami serta mengerti keilmuan hukum dalam bidang kenotariatan serta secara khusus bila melihat dari rumusan masalah yaitu memiliki tujuan mengetahui bagaimanakah pengaruh dari berkembangannya teknologi informasi dan komunikasi (TIK) pada aspek administratif dan aspek materi (substansi) terhadap Notaris.

\section{Metode Penelitian}

Metode penelitian yang digunakan adalah penelitian hukum normatif dimana peneliti menggunakan bahan hukum primer, yaitu bahan-bahan hukum yang berupa perundang-undangan, bahan hukum sekunder, yaitu bahan hukum yang memberi pemahaman atau menjelaskan pada bahan hukum primer itu sendiri, contohnya buku-buku dari para ahli hukum, dan bahan hukum tersier, yaitu bahan hukum yang memberi pemahaman atau menjelaskan tentang bahan hukum sekunder dan bahan hukum primer, contohnya yaitu kamus umum, ensiklopedi, dan seterusnya.

\section{Hasil Dan Pembahasan}

3.1 Pengaruh Perkembangan Teknologi Informasi dan Komunikasi terhadap Aspek Administratif dari Jabatan Notaris

Perkembangan pesat TIK telah mendorong penggunaan media elektronik dalam aktivitas sehari-hari sehingga melahirkan istilah-istilah antara lain electronic commerce (e-commerce), electronic learning (e-learning), dan electronic government (e-government). E-government adalah, "the use of electronic 
communications devices, computers and the Internet to provide public services to citizens and other persons in a country or region". ${ }^{12}$ (penggunaan perangkat komunikasi elektronik, komputer dan internet untuk memberikan pelayanan publik kepada warga negara dan orang lain dalam suatu negara atau wilayah). Selanjutnya diberi keterangan bahwa, menurut Jeong, 2007, istilah mencakup hubungan digital antar negara dengan pemerintahnya $(\mathrm{C} 2 \mathrm{G})$, antar pemerintah dengan badan pemerintah lainnya (G2G), antar pemerintah dan masyarakat itu sendiri (G2C), serta antar pemerintah dengan pegawai (G2E), dan antar pemerintah dan bisnis (G2B). ${ }^{13}$

Banyak pemerintah, termasuk Pemerintah Indonesia, telah memanfaatkan atau setidaknya mulai berupaya memanfaatkan media elektronik untuk memberikan layanan kepada masyarakat ataupun memperoleh data/informasi dari masyarakat. Dalam lingkup Pemerintah Indonesia, Kementerian Hukum dan Hak Asasi Manusia merupakan kementerian telah memanfaatkan TIK diantaranya untuk pendaftaran Notaris sampai pada kegiatan-kegiatan lainnya dari Notaris.

Penggunaan TIK melalui situs internet telah dimulai sejak seseorang hendak mendaftarkan dirinya sebagai Notaris. Ketika seseorang hendak mendaftar sebagai Notaris maka ia harus masuk ke situs internet Direktorat Jenderal Administrasi Hukum Umum, ${ }^{14}$ yang adalah bagian dari Kementerian Hukum dan HAM, di mana pada situs ini dapat ditemukan jalan pintas (shortcut) Pendaftaran Notaris. Melalui situs akan dijalani tahap-tahap pengisian data, unggah dokumen tertentu setelah di-scan termasuk juga pasfoto, dan print dokumen voucher untuk pembayaran; selanjutnya melakukan pembayaran dan mengirim manual (atau membawa langsung) dokumen-dokumen yang disyaratkan; kemudian mengunggah bukti pembayaran dan bukti pengiriman berkas. Jika ditimbang bahwa calon Notaris memenuhi syarat maka diterbitkan Surat Keputusan Menteri Hukum dan HAM tentang pengangkatan Notaris oleh bersangkutan bisa diunduh dari situs Ditjen AHU. Dalam proses ini pemohon tidak perlu tatap muka dengan pejabat dari Kementerian Hukum dan HAM ataupun Ditjen AHU; walaupun selain aktivitas paperless method ada juga aktivitas paper-based method berupa pengiriman (atau menyerahkan langsung) dokumen-dokumen fisik yang disyaratkan (ijazah dan sebagainya). $15 / 03 / 2019$

${ }^{12}$ Wikipedia, "E-Government", https://en.wikipedia.org/wiki/E-government, diakses tanggal

${ }^{13}$ Ibid.

${ }^{14}$ Direktorat Jenderal Administrasi Hukum Umum, “Ditjen AHU Online”, https://ahu.go.id/, diakses tanggal 15/03/2019. 
Setelah diangkat dan disumpah sebagai Notaris, aktivitas-aktivitas tertentu dari Notaris tetap harus dilakukan dengan melalui situs Ditjen AHU Online antara lain aktivitas Kenotariatan yang lebih bersifat administratif, di mana dalam situs dikemukakan. Situs Ditjen AHU Online juga menyediakan beberapa jalan pintas seperti layanan berkenaan dengan badan hukum (Perseroan Terbatas, Yayasan, dan Perkumpulan), layanan berkenaan dengan wasiat, dan layanan berkenaan dengan fidusia, sehingga orang yang misalnya hendak mengajukan permohonan pesan nama Perseroan Terbatas dan permohonan pengesahan Perseroan Terbatas, tinggal menggunakan layanan yang disediakan melalui situs ini.

Penggunaan TIK, selain dimanfaatkan untuk e-government sehingga antara lain hubungan antara Pemerintah dan Notaris dapat dilakukan melalui situs internet dan media elektronik, juga dapat dimanfaatkan oleh Notaris itu sendiri untuk efektivitas perkantoran. Notaris, saat memberi pelayanan pada bagian kenotariatan, dapat melakukan komunikasi dengan klien melalui sarana TIK seperti e-mail, untuk mengirim rancangan akta atas permintaan klien yang sedang melakukan perjalanan ke tempat yang jauh dari kantor Notaris.

Di samping pengaruh positif dari perkembangan TIK yang menyediakan sarana-sarana seperti situs internet dan e-mail, dapat juga terjadi adanya kemungkinan pengaruh negatif dari perkembangan TIK di mana kemudahan komunikasi melalui situs internet dapat disalahgunakan oleh Notaris untuk melakukan aktivitas yang dilarang. Salah satu larangan dalam Kode Etik Notaris yaitu Notaris dilarang melakukan mempromosikan diri atau mempublikasikan diri di mana pada Pasal 4 angka 3 UUJNP mengatur hal tersebut.

Keberadaan media internet yang mudah diakses dengan sendirinya dapat memberikan kemudahan kepada Notaris yang berkehendak melakukan publikasi atau promosi diri. Terdapat beberapa halaman yang dapat digunakan oleh notaris, seperti instagram, blogspot, kaskus, wordpress scribd, multiply, yahoo, facebook, twitter, path dan masih banyak lagi. Banyak kita jumpai notaris yang mempunyai blog maupun laman jejaring sosial lainnya dan mereka juga mencantumkan nama dan jabatannya agar bertujuan menarik perhatian masyarakat. ${ }^{15}$ Hal tersebut sudah jelas dilarang dalam Kode Etik Notaris. Oleh karenanya sebaiknya jika pengurus Ikatan Notaris Indonesia

\footnotetext{
${ }^{15}$ Ryan Saputra, Gunawan Djajaputra, (2018), Penegakkan Hukum Terhadap Notaris Yang Mempromosikan Diri Melalui Media Sosial, Jurnal Hukum Adigama, Vol 1. No. 1
} 
(INI) di semua tingkatan dapat senantiasa memberikan pengarahanpengarahan tentang pemanfaatan teknologi informasi dan komunikasi dari aspek Kode Etik Notaris dalam pertemuan-pertemuan yang dilakukan secara berkala.

\subsection{Pengaruh Perkembangan Teknologi Informasi dan Komunikasi Terhadap Aspek Materi (Substansi) Pekerjaan Notaris}

UUJN yang telah direvisi pada bagian menimbang huruf b mengatakan bahwa alat bukti tertulis yang sifatnya autentik sangat dibutuhkan untuk menjamin kepastian hukum, perlindungan dari suatu perjanjian atau perbuatan-perbuatn hukum yaitu dibuat oleh para pejabat berwenang; selanjutnya dalam huruf c dikatakan yakni Notaris ialah seorang pejabat umum dimana sedang melakukan tanggungjawabnya kepada masyarakat perlu diberikan jaminan dan perlindungan hukum untuk terwujudnya kepastian hukum. Bagian menimbang ini menekankan pada kepastian hukum sebagai sesuatu yang perlu diberikan kepada Notaris melalui UUJN.

Kepastian hukum (Bld.: rechtszekerheid; Ingg.: legal certainty), menurut N.E. Algra et al, adalah ketentuan tentang suatu hal yang dibolehkan dan yang tidak dibolehkan menurut hukum dan mengenai hak dan kewajiaban. ${ }^{16}$ Aspek yang penting dari suatu kepastian hukum adalah putusan hakim karena hal itu dapat diramalkan terlebih dahulu. ${ }^{17}$ Menurut L.J. van Apeldoorn, kepastian hukum mempunyai dua bagian, ialah: 1. tentang yang bisa diatur oleh (bepaalbaarheid) hukum pada suatu perihal yang konkrit, yaitu sebelum para pihak-pihak yang memulai perkara terlebih dahulu mencari tahu apakah dasar hukumnya dari suatu hal yang khusus. Menurut Roscoe Pound yang adalah bagian predictability (kemungkinan meramalkan). 2. Hukum yang pasti adalah hukum yang bisa memberi rasa aman, diamana artinya ialah perlindungan hukum untuk pihak berperkara dari tindakan kesewenang-wenangan hakim. ${ }^{18}$

Dengan adanya tujuan memberikan kepastian hukum bagi Notaris dalam menjalan profesinya memberi jasa hukum pada masyarakat luas, maka Notaris juga seharusnya berpegang teguh kepada UUJN sebagai yang dapat memberikan kepastian hukum baginya. Jika keluar dari ketentuan-ketentuan dalam UUJN ada kemungkinan Notaris dikenakan "sanksi sebagai bentuk

\footnotetext{
${ }^{16}$ N.E. Algra et al, 1983, Mula Hukum, terjemahan J.C.T. Simorangkir dari Rechtsaanvang. Jakarta, Binacipta, Hal 44.

17 Ibid.

${ }^{18}$ L.J. van Apeldoorn, 2001, Pengantar Ilmu Hukum, terjemahan Oetarid Sadibo dari Inleiding tot de studie van het Nederlandse recht, cet. 29, Jakarta, Pradnya Paramita, Hal 117.
} 
pertanggungjawaban Notaris", ${ }^{19}$ di mana sanksi ini mencakup aspek tanggung jawab keperdataan, aspek pertanggungjawaban administratif, dan aspek pertanggungjawaban pidana, tergantung dari kasusnya.

Bagian penting pegangan bagi Notaris dalam kepastian hukum yaitu dalam Pasal 16 ayat (1) huruf $m$ UUJN yang telah direvisi dimana ditentukan bahwa salah satu hal yang wajib bagi Notaris untuk membacakan aktanya di hadapan para pihak dan saksi yaitu saksi yang hadir minimal 2 orang saksi dan 4 orang saksi untuk akta wasiat dibawah tangan kemudian ditandatangani oleh Notaris, para pihak dan saksi disaat pembuatan akta tersebut. Ketentuan ini menunjukkan bahwa untuk kepastian hukum maka kehadiran penghadap dan saksi di hadapan Notaris adalah kehadiran secara fisik dan semuanya bertandatangan secara fisik.

Menurut Habib Adjie, pelanggaran pada Pasal 16 ayat (1) huruf m UUJN yang telah direvisi sering dilakukan jika Notaris menerima dan membuat berpuluhpuluh akta dalam sehari kerja seperti kredit pemilikan rumah (KPR) sehingga tidak sempat membacakan dan menerima tamu/penghadap satu persatu. Begitu juga jika berhadapan dengan mereka yang pada saat ini mempunyai kekuasaan/jabatan tertentu sehingga sibuk dan tidak mempunyai waktu untuk menghadap Notaris. Selain itu, meskipun hanya satu Akta, karena tebalnya berpuluh-puluh lembar, Akta jarang yang dibacakan secara utuh. ${ }^{20}$ Pelanggaran ketentuan seperti ini sebenarnya "dapat dikenakan sanksi berupa akta yang dibuat di hadapan Notaris hanya mempunyai kekuatan pembuktian sebagai akta di bawah tangan atau suatu akta menjadi batal demi hukum, dan juga merugikan para pihak yang bersangkutan maka pihak tersebut dapat menuntut biaya, ganti rugi dan bunga kepada Notaris".

Dalam era perkembangan TIK dan sarana-sarananya seperti media internet sekarang ini, Indonesia telah berupaya mengikuti perkembangan antara lain dalam pembuatan UU PT telah diatur tentang Rapat Umum Pemegang Saham (RUPS) yang bisa dibuat secara fisik, maupun didalam Pasal 77 ayat (1), yaitu RUPS juga bisa dilaksanakan lewat cara video konferensi, media telekonferensi dan media-media elektronik lainnya mungkin dapat digunakan oleh keseluruhan anggota RUPS untuk dapat mendengarkan dan melihat dengan

\footnotetext{
${ }^{19}$ Sjaifurrachman dan Habib Adjie, 2011, Aspek Pertanggungjawaban Notaris dalam Pembuatan Akta, Bandung, Mandar Maju, Hal 194.

${ }^{20}$ Habib Adjie, 2009, “Akta Tidak Dibacakan Bukan Suatu Pelanggaran (Menurut Pasal 84 Undang-Undang Jabatan Notaris)”, dalam Meneropong Khazanah Notaris dan PPAT Indonesia (Kumpulan Tulisan tentang Notaris dan PPAT), Bandung, Citra Aditya Bakti, Hal 105.
} 
langsung juga ambil bagian didalam rapat. Selanjutnya dalam Pasal 77 ayat (4) ditentukan didalam tiap pelaksanaan RUPS seperti yang dimaksudkan dalam ayat (1) haruslah dibuat suatu risalah rapat dimana ditandatangani serta disetujui seluruh peserta RUPS, pada penjelasan pasal diberikan keterangan yang dimaksudkan "disetujui dan ditandatangani" ialah ditandatangani serta disetujui secara elektronik dan secara fisik. Ketentuan Pasal 77 UU PT menunjukkan bahwa untuk dilakukannuya RUPS, Undang-Undang membolehkan dilakukannya RUPS melalui video, media dan sarana eletronik lain, tidak perlu bertandatangan secara fisik tapi dapat bertandatangan secara elektronik.

Mengenai penyelenggaraan RUPS dengan menggunakan media elektronik, dikatakan oleh Binoto Nadapdap,

Kemajuan pada bidang teknologi komunikasi serta transportasi membuat pemegang saham bisa berpidah dari satu tempat ke tempat lain dengan cepat. Di samping itu, dengan kemajuan tekonologi ini, tidak menutup kemungkinan pemegang saham bisa melakukan urusannya yang berhubungan dengan perusahaan dengan tidak perlu hadir secara fisik di tempat mana Rapat Umum Pemegang Saham berlangsung. Dengan mempergunakan tele conference misalnya, pemegang saham dapat mengikuti dan terlibat langsung atau berpartisipasi dalam RUPS dari jarak jauh.

Mengenai pengaruh dari teknologi terhadap pelaksanaan RUPS sudah diantisipasi oleh UU No. 40 tahun 2007. Hal ini terlihat dengan jelas dalam rumusan pasal 77 ayat (1) UU PT menentukan bahwa kecuali dari pelaksanaan RUPS seperti dimaksudkan pada pasal 76, RUPS bisa saja dibuat lewat media telekonferensi, video konferensi, atau sarana lain juga mengambil bagian didalam rapat. Rumusan yang sedemikian rupa, maka alah satu kendala bagi pemegang saham untuk mengikuti rapat dari jarak jauh tanpa kehadiran fisik sudah diakomodir oleh UU PT.

Ketentuan yang membolehkan RUPS lewat video dan media telekonferensi, serta media elektronik lain dipandang sebagai hal yang positif, yaitu mendukung terlaksananya RUPS yang lebih sesuai dengan kebutuhan para pemegang saham yang bergerak laju dari suatu tempat ke tempat yang lainnya. Walau demikian, di tahun 2007 belum ditemukan suatu undang-undang yang mengatur tentang ketentuan-ketentuan umum dari informasi dan dokumendokumen elektronik serta tanda tangan secara elektronik. 
Undang-Undang Teknologi Informasi dan Komunikasi (UU ITE) telah direvisi pada Pasal 1 angka 1 memberi definisi bahwa "Informasi Elektronik adalah satu atau sekumpulan data elektronik, termasuk tetapi tidak terbatas pada tulisan, suara, gambar, peta, rancangan, foto, electronic data interchange (EDI), surat elektronik (electronic maill, telegram, teleks, telecopy atau sejenisnya, huruf, tanda, angka, Kode Akses, simbol, atau perforasi yang telah diolah yang memiliki arti atau dapat dipahami oleh orang yang mampu memahaminya"21; selanjutnya pada Pasal 1 angka 4 memberi definisi perihal Dokumen Elektronik ialah semua informasi-informasi Elektronic yang diterima, dikirim, dilanjutkan penyimpanannya dan dibuat berbentuk digital, analog, optical, elektromanetik dan semacamnya, yang bisa didengar, diketahui dan dimunculkan lewat komputer namun tidaklah dibatasi kepada tulisan, gambaran, suara, perencanaan, peta, foto-foto dan atau seperti angka, tanda, kode, huruf, simbolsimbol dan atau perforasi yang boleh diketahui dan dimengerti juga memilki makna.22; kemudian pada Pasal 5 ayat (1) UU ITE ditegaskan bahwa suatu Dokumen Elektronic atau Informasi Elektronic hasil cetakkannya adalah alat pembuktian atau bukti hukum yang sah.

Definisi informasi elektronik dan dokumen elektronik dalam UU ITE tidak menyebut tentang telekonferensi atau video konferensi. Tetapi definisi Pasal 1 angka 1 dan angka 4 UU ITE hanya menyebut "termasuk tetapi tidak terbatas pada" sehingga apa yang disebutkan dalam definisi-definisi itu tidak bersifat limitatif (membatasi). Telekonferensi dan video konferensi menggunakan data elektronik sehingga dapat dipandang termasuk ke dalam pengertian informasi elektronik dan video elektronik. Dengan demikian, apa yang ditampilkan dan direkam dalam kegiatan relekonferensi atau video konferensi adalah alat pembuktian hukum sah.

UU ITE dan revisinya juga mengatur tentang Tanda Tangan Elektronik. Pasal 1 angka 12 UU ITE yang telah direvisi definisi Tanda Tangan Elektronik ialah suatu tanda tangan eletronic melekat, terasosikan dan berhubungan dengan Informasi Elektronic lain dipakai seperti sebuah peralatan autentikasi dan verifikasi. Tanda Tangan Elektronik selanjutnya diatur pada Pasal 11 dan Pasal 12 UU ITE.

${ }^{21}$ Undang-Undang Nomor 19 Tahun 2016 tentang Perubahan Atas Undang-Undang Nomor 11

Tahun 2008 tentang Informasi dan Transaksi Elektronik (Lembaran Negara Republik Indonesia Tahun 2016 Nomor 251, Tambahan Lembaran Negara Republik Indonesia Nomor 5952).

22 Ibid. 
UU ITE dan revisinya merupakan Undang-Undang yang menjadi dasar untuk segala aturan hukum yang masih ada hubungan dengan pemanfaatan TIK, di mana dapat dikatakan bahwa UU ITE memberikan dukungan hukum yang kuat terhadap keabsahan dari penggunaan video konferensi dan media telekonferensi, serta tanda tangan elektronik dalam Undang-Undang Perseroan Terbatas.

Jika suatu risalah RUPS dibuatkan Akta Notaris, maka Notaris akan dihadapkan pada permasalahan antara, di satu pihak, perintah Pasal 16 ayat (1) huruf $m$ UUJNP yang telah direvisi yang mewajibkan kehadiran penghadap dan saksi di hadapan Notaris secara fisik dan semuanya bertandatangan secara fisik, dan, di lain pihak, ketentuan UU PT yang pada Pasal 77 yang membolehkan RUPS dibuat lewat video konferensi, media telekonferens, dan dengan media elektronik lain, sedangkan risalah rapat dapat disetujui dan ditandatangani secara elektronik. Ketentuan dalam UU PT ini kemudian didukung oleh UU ITE mengatur peraturan umum tentang dokumen elektronik dan informasi serta tanda tangan elektronik.

Dalam hal tersebut dapat dikatakan terjadi benturan (konflik) antara norma dalam UUJN di satu pihak norma dalam UU PT dan UU ITE di lain pihak. Persoalan benturan antarnorma ini secara teoritis dapat dikaji dari sudut yang oleh Hans Kelsen disebut concept of derogation (konsep penyampingan), di mana oleh Hans Kelsen dikatakan bahwa, "A very particular normative function is that which consists in the repeal of the validity of another norm, and which is called derogation. It plays an important part in a positive legal order"23 (Suatu fungsi normatif sangat khusus adalah bahwa yang terdiri dari pencabutan keabsahan norma lain, dan yang disebut penyampingan. Hal ini memainkan bagian penting dalam tatanan hukum positif).

Konsep penyampingan yang dapat digunakan dalam kasus ini yaitu konsep lex specialis derogat legi generali, ialah "ketentuan khusus mengesampingkan ketentuan umum" 24. Ketentuan Pasal 16 ayat (1) huruf m UUJNP telah direvisi merupakan peraturan umum karena ketentuan tersebut, khususnya frasa "membacakan Akta di hadapan penghadap dengan dihadiri oleh paling sedikit 2 (dua) orang saksi ... dan ditandatangani pada saat itu juga oleh penghadap, saksi, dan Notaris", pada dasarnya berlaku bagi pembuatan semua akta.

${ }^{23} \mathrm{Ibid}$.

${ }^{24}$ Donald A. Rumokoy dan Frans Maramis, Pengantar Ilmu Hukum, ed.1 cet.3, Rajawali Pers, Jakarta, 2016, hlm. 147. 
Ketentuan Pasal 77 ayat (1) dan ayat (4) UU PT merupakan ketentuan yang hanya berlaku untuk Perseroan Terbatas dalam melakukan RUPS lewat video konferensi, media telekonferensi, dan atau sarana media elektronik lain, sehingga pembuatan Akta tentang risalah RUPS melalui video konferensi, media telekonferensi, dan atau sarana media elektronik lain merupakan aturan khusus. Dengan demikian, berlaku konsep lex specialis derogat legio generali, yaitu ketentuan pembuatan Akta untuk risalah RUPS yang dilakukan melalui video konferensi, media telekonferensi, atau sarana media elektronik lain, menyampingkan ketentuan Pasal 16 ayat (1) huruf m UUJN yang telah direvisi.

Penyampingan aturan didalam Pasal 16 ayat (1) huruf m UUJN yang telah direvisi oleh ketentuan pembuatan Akta risalah RUPS untuk RUPS yang dibuat melalui sarana media elektronik ini, tidak berarti bahwa Pasal 16 ayat (1) huruf $\mathrm{m}$ tersebut untuk selanjutnya tiada lagi memilki kekuatan hukum sempurna dan mengikat bagi setiap produk akta Notaris. Penyampingan di sini hanyalah dalam arti bahwa Pasal 16 ayat (1) huruf m kehilangan kekuatan hukum didalam menghadapi peristiwa membuat Akta Notaris risalah RUPS untuk RUPS dilakukan melalui sarana media elektronik yang dimaksudkan. Pasal 16 ayat (1) huruf $\mathrm{m}$ tetap berlaku dan memiliki kekuatan hukum mengikat dalam pembuatan Akta Notaris lainnya.

Dari sudut kajian hukum/ilmiah, konsep lex specialis derogat legi generali ini dapat dipakai untuk menyesuaikan ketentuan-ketentuan dalam UUJN dalam menghadapi berbagai Undang-Undang lainnya yang telah mengakomidir perkembangan TIK. Walaupun demikian, dalam tingkat praktis Notaris senantiasa akan merasa ragu tentang kepastian hukum dalam pekerjaannya di mana ada kemungkinan Notaris menjadi tersangka karena dianggap tidak sejalan dengan aturan pada Pasal 16 ayat (1) huruf m UUJN. Oleh karenanya, sebaiknya pengaruh TIK dan sarana-sarananya terhadap profesi Notaris menjadi perhatian untuk dimasukkan ke dalam pembaruan Nota Kesepahaman antara POLRI dan Ikatan Notaris Indonesia.

\section{Kesimpulan dan Saran}

Dari hasil diatas dapat diambil kesimpulan yaitu pengaruh perkembangan teknologi informasi dan komunikasi terhadap aspek administratif dari Jabatan Notaris memiliki segi positif, seperti dimanfaatkan untuk e-government dalam komunikasi antara Calon Notaris/Notaris dengan Pemerintah dan 
dimanfaatkan untuk peningkatan efektivitas perkantoran; tetapi dapat juga memiliki segi negatif yaitu dapat disalahgunakan oleh Notaris untuk melakukan tindakan yang tidak dapat dibenar seperti melakukan publikasi atau promosi diri. Selanjutnya pengaruh perkembangan teknologi informasi dan komunikasi terhadap aspek materi (substansi) pekerjaan Notaris, yaitu Notaris dapat menghadapi benturan antara aturan didalam UUJN dan ketentuan undang-undang membolehkan penggunaan TIK seperti media elektronik, misalnya benturan antara kewajiban Notaris pada Pasal 16 ayat (1) huruf m UUJNP dengan pembuatan Akta Notaris Risalah RUPS untuk RUPS dibuat dengan cara video konferens, media telekonferens, atau sarana media elektronik lain. Adapun saran dapat diberikan yaitu sebaiknya pengurus Ikatan Notaris Indonesia di semua tingkatan dapat senantiasa memberikan pengarahan-pengarahan tentang pemanfaatan teknologi informasi dan komunikasi dari aspek Kode Etik Notaris dalam pertemuan-pertemuan yang dilakukan secara berkala. Dan dalam menghadapi benturan antara ketentuan dalam UUJN dan didalam aturan undang-undang lain telah mengakomodir teknologi komunikasi dan informasi juga sarana-sarana, dari segi ilmiah dapat digunakan konsep lex specialis derogat legi generali, sedangkan untuk segi praktis sebaiknya pengaruh tekonologi informasi dan komunikasi serta saranasarananya terhadap profesi Notaris menjadi perhatian untuk dimasukkan ke dalam pembaruan Nota Kesepahaman antara POLRI dan Ikatan Notaris Indonesia.

\section{Ucapan terima Kasih (Acknowledgments)}

Terima kasih atas semua perkenanan dan penyertaan Tuhan Yesus, rachmat dan kasihNya kepada penulis yang telah memberikan cukup waktu sehingga penelitian ini dapat diselesaikan dengan segala baik. Penulis juga berterima kasih atas semua fasilitas dan kesempatan yang diberikan oleh Fakultas Hukum Universitas Udayana serta para dosen, staf dan semua teman-teman yang telah meluangkan waktu dan tenaga dalam penyelesaian penelitian ini. 


\section{Daftar Pustaka / Daftar Referensi}

\section{$\underline{\text { Buku }}$}

Anshori, Abdul Ghofur. (2009). Lembaga Kenotariatan Indonesia. Perspektif Hukum dan Etika. Yogyakarta. UII Press.

Adjie, Habib. (2009). Meneropong Khazanah Notaris dan PPAT Indonesia (Kumpulan Tulisan tentang Notaris dan PPAT). Bandung: Citra Aditya Bakti.

Apeldoorn, L.J. van. (2001). Pengantar Ilmu Hukum, terjemahan Oetarid Sadibo dari Inleiding tot de studie van het Nederlandse recht. Jakarta: Pradnya Paramita.

Koops, Bert-Jaap, C. Prins dan H. Hijmans (ed.), (2000). ICT Law and Internationalisation. A Survey of Government Views. Kluwer Law International. Netherland: The Hague.

Nadapdap, Binoto. (2016). Hukum Perseroan Terbatas. Berdasarkan UndangUndang No. 40 Tahun 2007. Jakarta: Jala Permata Aksara.

Rumokoy, Donald A. dan Frans Maramis. (2016). Pengantar Ilmu Hukum. Jakarta: Rajawali Pers.

Sjaifurrachman dan Habib Adjie. (2011). Aspek Pertanggungjawaban Notaris dalam Pembuatan Akta. Bandung: Mandar Maju.

\section{Jurnal}

Benny. (2015). Penetapan Konsep Cyber Notary di Indonesia ditinjau dari Undang-Undang Nomor 2 Tahun 2014. Premise Law Jurnal. Vol 5.

Dharmawan, N.K.S. (2015). Keberadaan Pemegang Saham Dalam Rups Dengan Sistem Teleconference Terkait Jaringan Bermasalah Dalam Perspektif Cyber Law. Udayana Master Law Jurnal. Vol. 4.

Fitriyeni, Cut Era. (2012). Tanggung Jawab Notaris Terhadap Penyimpanan Minuta Akta Sebagai Bagian Dari Protokol Notaris. Kanun Jurnal Ilmu Hukum. Tahun XIV. No. 58.

Makarim, Edmon. (2011). Modernisasi Hukum Notaris Masa Depan: Kajian Hukum Terhadap Kemungkinan Cyber Notary Di Indonesia. Jurnal Hukum Dan Pembangunan Tahun 41. No. 3.

Sai, Dewa Ayu Widya., Murni, R.A Retno., Udiana, I.M. (2017). Kewenangan Notaris Di Bidang Cyber Notary Berdasarkan Pasal 15 Ayat (3) Undang- 
Undang Nomor 2 Tahun 2014 Tentang Perubahan Atas UndangUndang Nomor 30 Tahun 2004 Tentang Jabatan Notaris. Acta Comitas. Vol 2.

Saputra, Ryan., Djajaputra, Gunawan. (2018). Penegakkan Hukum Terhadap Notaris Yang Mempromosikan Diri Melalui Media Sosial. Jurnal Hukum Adigama. Vol 1.

Utama, I Made Arya., Kasih, Desak Putu Dewi. (2017). Penyimpanan Protokol Notaris Secara Elektronik Dalam Kaitan Cyber Notary. Acta Comitas Vol 2.

\section{Sumber Internet/Dokumen Elektronik}

Direktorat Jenderal Administrasi Hukum Umum.“Ditjen AHU Online”. https://ahu.go.id/. diakses tanggal 15/03/2019.

INI.id. "Perubahan Kode Etik Notaris Kongres Luar Biasa Ikatan Notaris Indonesia.Banten.29-

30Mei2015".http://ini.id/apps/public/file/kode_etik/Perubahan_KEN_h asil_KLB_2015.pdf. diakses tanggal 15/03/2019.

United Nations. "UNCITRAL Model Law on Electronic Commerce wih Guide to Enactment 1996 with additional article 5 bis as adopted in 1998". http://www.uncitral.org/pdf/english/texts/electcom/0589450_Ebook.pdf. diakses tanggal 15/03/2019.

Wikipedia. "E-Government". https://en.wikipedia.org/wiki/E-government. diakses tanggal 15/03/2019.

\section{Undang-undang}

Undang-Undang Nomor 30 Tahun 2004 tentang Jabatan Notaris (Lembaran Negara Republik Indonesia Tahun 2004 Nomor 117, Tambahan Lembaran Negara Republik Indonesia Nomor 4432).

Undang-Undang Nomor 40 Tahun 2007 tentang Perseroan Terbatas (Lembaran Negara Republik Indonesia Tahun 2007 Nomor 106, Tambahan Lembaran Negara Republik Indonesia Nomor 4756).

Undang-Undang Nomor 11 Tahun 2008 tentang Informasi dan Transaksi Elektronik (Lembaran Negara Republik Indonesia Tahun 2008 Nomor 58, Tambahan Lembaran Negara Nomor 4843).

Undang-Undang Nomor 2 Tahun 2014 tentang Perubahan Atas UndangUndang Nomor 30 Tahun 2004 tentang Jabatan Notaris (Lembaran Negara 
Republik Indonesia Tahun 2014 Nomor 3, Tambahan Lembaran Negara Republik Indonesia Nomor 5491).

Undang-Undang Nomor 19 Tahun 2016 tentang Perubahan Atas UndangUndang Nomor 11 Tahun 2008 tentang Informasi dan Transaksi Elektronik (Lembaran Negara Republik Indonesia Tahun 2016 Nomor 251, Tambahan Lembaran Negara Republik Indonesia Nomor 5952). 